Структура та зміст підсумкового контролю в тестовій формі $з$ дисципліни «Лінійна алгебра»

УДК 378.091.27:512.64

\title{
СТРУКТУРА ТА ЗМІСТ ПІДСУМКОВОГО КОНТРОЛЮ В ТЕСТОВІЙ ФОРМІ 3 ДИСЦИПЛІНИ «ЛІНІЙНА АЛГЕБРА»
}

\author{
Зоя Пащенко \\ кандидат фізико-математичних наук, доцент \\ доцент кафедри методики навчання математики \\ та методики навчання інформатики \\ ДВНЗ «Донбаський державний педагогічний університет», \\ м. Слов'янськ Донецької області, Україна \\ ORCID ID 0000-0003-4544-9242 \\ pashchenko_zd@i.ua \\ Тетяна Турка \\ кандидат фізико-математичних наук, доцент \\ доцент кафедри методики навчання математики \\ та методики навчання інформатики \\ ДВНЗ «Донбаський державний педагогічний університет», \\ м. Слов'янськ Донецької області, Україна \\ ORCID ID 0000-0001-6445-2223 \\ tvturka@gmail.com
}

\begin{abstract}
Анотація У статті обгрунтовано вибір виду контрольно-оціночних заходів у вигляді тестів для студентів бакалаврського (першого) освітнього рівня, а саме: розглянуто можливість та необхідність застосування підсумкового контролю 3 «Лінійної алгебри» у вигляді тесту. Виділено перші етапи складання тесту, це визначення змісту навчального матеріалу, побудова технологічної матриці, підбір змісту тестових завдань відповідно до обраних форм тестів, розподіл тестових завдань між білетами з урахуванням відповідності технологічній матриці та рівносильності за складністю.

Розглянувши різні форми тестів, у роботі виділено ті, які, на думку авторів, найоптимальніше можуть виконати функцію контролю математичних дисциплін. Це тести типу правильно/неправильно, із вибором однієї правильної відповіді, на визначення відповідності, на отримання числової відповіді та відкритого типу. Наведено приклади різних форм тестів підсумкового контролю з дисципліни «Лінійна алгебра» для бакалаврів фізикоматематичного факультету ДВНЗ «ДДПУ» спеціальності 014 Середня освіта (Математика).

Ключові слова: контроль знань; тестування; етапи складання тестів; форми тестів; підсумкова атестація; лінійна алгебра.
\end{abstract}

Постановка проблеми. Процес об’єднання Європи, його поширення на Схід і країни Балтійського регіону супроводжується формуванням єдиного освітнього й наукового простору та запровадженням уніфікованих вимог, критеріїв і стандартів національних систем вищої освіти.

Для сучасного розвитку системи освіти України характерними є модернізація та спрямованість до західного зразка освіти, як такого, що добре

(ㄷ ДВНЗ «Донбаський державний педагогічний університет» 
Структура та зміст підсумкового контролю в тестовій формі $з$ дисципліни «Лінійна алгебра»

зарекомендував себе в розвитку. Також приєднання України до Болонського процесу стимулює входження до європейського освітнього та наукового простору. У межах цього процесу передбачається провести певні зміни, які повинні забезпечити підвищення якості підготовки фахівців. Необхідною умовою $є$ розвиток та вдосконалення форм і методів контролю навчальних досягнень, які реалізують зворотний зв'язок у навчанні. Крім того, система оцінок повинна бути універсальною і єдиною для всіх країн учасників Болонського процесу.

Проблема підвищення ефективності та надійності контролю якості освіти завжди була актуальною, що зумовило докладне й серйозне ставлення до неї.

Однією з форм автоматизованого контролю $є$ тестування - процедура, що дозволяє отримати об'єктивну, оперативну та достовірну інформацію про знання студентів, отримані в процесі навчання, про готовність до сприйняття нового матеріалу. I хоча, безумовно, тестування не повинно бути єдиним способом контролю, проте в багатьох випадках допомагає провести його швидко та якісно.

Практичне завдання полягає в створенні змісту тестових завдань для перевірки остаточних знань з урахуванням відповідності вимогам, які існують до засобів контролю такого роду.

Аналіз останніх досліджень і публікацій. Контрольно-оціночні заходи результатів навчання студентів у Німеччині близькі до тих, що практикують українські ЗВО, і включають поточний та підсумковий контроль, основними формами якого є заліки й іспити. Загалом практика німецьких університетів доводить, що відсутність екзаменаційного перевантаження сприятливо впливає на якість навчання. Сучасна система контролю й оцінювання загалом відповідає основним положенням Болонської декларації і $\epsilon$ важливим механізмом отримання високих якісних стандартів вищої освіти в Німеччині. Водночас ця система забезпечує інтернаціональну освітню мобільність студентів та покращує шанси випускників на працевлаштування в країнах-учасниках Болонського процесу. Оцінка результатів навчання, крім свого прямого призначення, має й інші аспекти. Наприклад, виявити сильні та слабкі сторони діяльності вишів і допомогти їм виробити стратегію забезпечення підвищення якості освіти (Плащовата, 2015).

У науковій літературі проблемі тестування приділено досить значну увагу. Фундаментальні педагогічні дослідження тестового контролю висвітлено в працях зарубіжних учених: В. Аванесова, Т. Аджер, А. Анастазі, В. Беспалька, Л. Бурлачука， Дж. Гласс， Н. Гронланда， Л. Долінера， Р. Ібел， К. Інгенкампа, П. Клайна, А. Майорова, Р. Намбельтона, В. Переверзєва, I. Раппопорта, 
Структура та зміст підсумкового контролю в тестовій формі з дисципліни «Лінійна алгебра»

Дж. Стенлі, М. Челишкової та ін. У західних країнах, особливо в США, за цей час удалося накопичити значний теоретичний і фактичний матеріал.

Тестовий контроль широко розглянуто і в працях українських науковців: Я. Болюбаша, І. Булаха, В. Гогунського, Л. Гриневич, А. Єріна, Л. Коваленка, О. Локшиної, К. Михайлова, М. Мруга, Л. Леонського, О. Ляшенко, М. Олійника, Л. Паращенко, Х. Порсєвої, Г. Терещука, Л. Фігурської, В. Хмельницького, В. Шпильового, О. Яковенко та ін.

Проблемі тестового контролю в значній кількості праць присвятив В. Аванесов (1994). Зокрема, у своїй дисертації він зауважив, що тести вможливлюють отримання об'єктивних оцінок рівня знань, умінь, навичок, перевірку відповідності вимог до підготовки випускників заданим стандартам, виявлення прогалин в підготовці студентів.

На думку російського вченого В. Каднєвського (2004), у сучасному світі тести стали важливою складовою життєдіяльності суспільства. Універсалізм, широта застосування, високий рівень об'єктивності одержуваних результатів визначають тести як феномен людської цивілізації.

Актуальність тестового методу пояснюється його перевагами перед іншими традиційними формами контролю:

- можливістю кількісного вимірювання рівня знань;

- повним охопленням знань під час тестового контролю;

- наявністю однакових для всіх правил проведення педагогічного контролю та адекватної інтерпретації тестових результатів;

- систематичністю контролю та індивідуальним підходом.

Ці переваги забезпечують умови створення якісних тестів.

Л. Кухар та В. Сергієнко (2010) у своєму курсі лекцій «Конструювання тестів» виділяють 16 етапів якісного створення тесту.

Процес підготовки тестів, описаний у багатьох літературних джерелах, передбачає, що складання тесту повинно проходити ряд етапів: визначення цілей тестування, визначення ресурсних можливостей розробників, відбір змісту навчального матеріалу, конструювання технологічної матриці і їі експертиза, складання тестових завдань та їхня експертиза, побудова вибірки для апробації завдань і тестів, компонування завдань для апробації, апробація тестових завдань, визначення i розрахунок показників якості тестових завдань, відбракування завдань і складання тесту, апробація тесту, визначення i розрахунок показників якості тесту, складання остаточного варіанта тесту, стандартизація тесту, нормування тесту, оснащення тесту.

Формулювання цілей статті (постановка завдання). Мета статті обгрунтувати вибір виду контрольно-оціночних заходів у вигляді тестів для 
Структура та зміст підсумкового контролю в тестовій формі $з$ дисципліни «Лінійна алгебра»

студентів бакалаврського (першого) освітнього рівня і на основі аналізу форм та етапів складання тестів, визначити зміст навчального матеріалу, вимоги до структури та змісту тестів на прикладі підсумкового контролю 3 дисципліни «Лінійна алгебра» для бакалаврів фізико-математичного факультету ДВНЗ «ДДПУ» спеціальності 014 Середня освіта (Математика).

Результати дослідження. Контроль - це невід’ємний складник процесу навчання. Він призначений для визначення та оцінювання рівня сформованості знань, навичок і вмінь та для зворотного впливу на навчальний процес після аналізу результатів контролю.

Основною системою оцінювання знань $з$ окремих дисциплін в українських вишах є стобальна. Отже, немає сенсу вигадувати іншу. Решта систем стали похідною від неї. Проте національна система оцінювання покликана визначити якість набутих компетентностей здобувачів. Якщо до 100-бальної системи оцінювання ставитись як до простої арифметики, то вона може не відображати показник якості. Тому зміст контрольних заходів повинен містити завдання різних рівнів складності, які вимагають застосування не лише репродуктивних, a і творчих умінь і навичок.

Педагогічним тестом є система паралельних завдань специфічної форми, які розташовуються за принципом зростання відповідно до складності порядку, що дозволяє якісно й ефективно виміряти рівень і структуру підготовки екзаменованих. Кожне тестове завдання має відповідати чітко визначеній формі, змісту, рівню складності. Лише якісні завдання забезпечують високу валідність (тест справді вимірює те, для чого його призначено) і надійність (наскільки точно тест вимірює досліджуване явище) тесту (Смолінчук, 2010).

Іспитам відведено останнє підсумкове місце. Існує 2 види іспиту: семестровий, який складається після закінчення курсу вивчення дисципліни та кваліфікаційний, що втілює основний рівень перевірки успішності. Іспит дає відповідь на питання, чи оволодів студент необхідними компетентностями, а саме: знаннями, уміннями і навичками для подальшої роботи за обраною спеціальністю. Це і $є$ основною метою іспиту. Форма проведення цих іспитів повинна бути узгоджена. Оскільки кваліфікаційний іспит планується проводити в тестовій формі, тому доречно і семестровий проводити в такій самій.

Робота над складанням безпосередньо тесту починається з відбору змісту навчального матеріалу, який повністю охоплює навчальну програму цієї дисципліни. Доречно весь зміст цього матеріалу розподілити за розділами. Використання питань із кожного розділу тестів забезпечить повне охоплення знань під час контролю. Нами визначено такий розподіл змісту програми дисципліни «Лінійна алгебра»:

Професіоналізм педагога: теоретичні й методичні аспекти. - Вип. 12. - Слов'янськ, 2020. 
1. Комплексні числа.

2. Матриці та визначники. Системи лінійних рівнянь.

3. Лінійна залежність та лінійна незалежність. Ранг.

4. Лінійний простір, базис, розмірність, координати.

5. Лінійні оболонки. Сума, перетин та пряма сума підпросторів.

6. Лінійний оператор, образ, ядро.

7. Власні значення, власні вектори, діагональна форма.

8. Евклідовий простір.

9. Квадратичні форми.

10. Відношення та відображення.

За метою використання та місцем у навчальному процесі розмежовують тести навчальні й контрольні. Навчальні тести використовуються на всіх етапах роботи над матеріалом і покликані відстежити рівень оволодіння матеріалом, закріпити або повторити його. Їхня головна мета - виявити прогалини в знаннях, уміннях, навичках студентів, спрямувати їх на усунення недоліків у підготовці. 3 огляду на це перевіряти такі тести можуть самі студенти. Контрольні тести проводяться як певний підсумок роботи над вивченням теми, вони мають комплексний характер, тобто перевіряють знання й уміння, здобуті й вироблені студентами в межах одного або кількох тематичних блоків.

За наявністю або відсутністю варіантів відповіді виділяють тести закритої та відкритої форм:

1) із вибором однієї правильної відповіді;

2) із можливістю множинного вибору;

3) на визначення відповідності;

4) на встановлення правильної послідовності;

5) відкритого типу (коротка відповідь, есе);

6) типу правильно/неправильно;

7) на отримання числової відповіді.

Тести відкритого типу (5) перевіряються викладачем, тести інших типів оцінюються автоматично.

Проаналізувавши переваги та недоліки різних типів тестів, підходячи до створення структури та змісту пакета тестів до іспиту з лінійної алгебри для майбутніх учителів математики, було обрано комбінований вид. На думку авторів, такий підхід найбільше задовольняє валідність та якість тестів.

Завдання формату 1 складається 3 умови (запитання, незакінченого твердження) та чотирьох варіантів вибору, один із яких правильний, а решта дистрактори (правдоподібні неправильні відповіді), функція яких - збити 3 пантелику учасників тестування, які не впевнені у відповіді. У дистракторах 
Структура та зміст підсумкового контролю в тестовій формі $з$ дисципліни «Лінійна алгебра»

моделюються типові помилки, яких припускаються студенти під час виконання відповідних завдань. Складність підготовки таких тестів полягає в підборі відповідей-дистракторів.

Завдання 3 однією правильною відповіддю вимірюють, переважно, репродуктивні вміння, знання та розуміння означень, властивостей теорем.

Якщо завдання має 4 варіанти відповіді, із яких лише один $є$ правильним, згідно зі статистикою цю відповідь можна вгадати 3 імовірністю 25\%, що позитивно впливає на надійність тесту.

Завдання 3 однією правильною відповіддю чи не найпоширеніші в практиці тестування, що пояснюється зручністю їхньої форми для автоматизації контролю навчальних досягнень та відносно високою надійністю. Прикладом такого завдання є:

Приклад 1. Дано лінійне перетворення $T: \boldsymbol{R}^{2} \rightarrow \boldsymbol{R}^{2}$ за допомогою матриці $T_{e}=\left(\begin{array}{cc}1 & -3 \\ -2 & 6\end{array}\right)$ в базисі е. Які числа є власними значеннями $T$ ?
A) -2
Б) 7 i 0
B) 7 i -3
Г) 0 i -3

Завдання типу 2, що передбачають вибір декількох правильних відповідей та завдання на встановлення правильної послідовності мало застосовуються в математиці, що пояснюється іiї специфікою.

Завдання закритої форми на встановлення відповідності (3) має основу та два стовпчики інформації, позначених цифрами (ліворуч) і буквами (праворуч). Виконання завдання передбачає встановлення відповідності (утворення «логічних пар») між інформацією, позначено цифрами та буквами. Як приклад наведемо таке завдання:

Приклад 2. Встановити відповідність між початками (1 - 4) $і$ кіниями (A - Д) істинних тверджень.

\begin{tabular}{|c|c|c|c|}
\hline 1 & $\begin{array}{l}\text { Якщо у визначнику поміняти } \\
\text { рядки місиями, то }\end{array}$ & $\mathbf{A}$ & $\begin{array}{l}\text { визначник одержаної матриці } \\
\text { не зміниться. }\end{array}$ \\
\hline 2 & $\begin{array}{l}\text { Якщо матрицю помножити } \\
\text { на число } k, \text { то }\end{array}$ & Б & $\begin{array}{l}\text { визначник одержаної матрищі } \\
\text { помножиться на число } k .\end{array}$ \\
\hline 3 & $\begin{array}{l}\text { Якщо рядок матричі } \\
\text { помножити на число } k \text {, то }\end{array}$ & B & $\begin{array}{l}\text { визначник одержаної матричі } \\
\text { буде дорівнювати нулю. }\end{array}$ \\
\hline 4 & $\begin{array}{l}\text { Якщо до одного рядка } \\
\text { матриці додати інший, } \\
\text { помножений на число } k \text {, то }\end{array}$ & $\Gamma$ & $\begin{array}{l}\text { визначник одержаної матриці } \\
\text { змінить знак на протилежний }\end{array}$ \\
\hline & & Д & Інше продовження. \\
\hline
\end{tabular}

Професіоналізм педагога: теоретичні й методичні аспекти. - Вип. 12. - Слов'янськ, 2020. 
Структура та зміст підсумкового контролю в тестовій формі $з$ дисципліни «Лінійна алгебра»

Імовірність угадування в тестах такої форми досить низька, наприклад у чотирьох завданнях та п'яти відповідях воно становить 1,7\%.

Не слід нехтувати тестами типу 6, де відповідь може бути «так» чи «ні» і висока ймовірність угадування (складає 50\%). У тесті комбінованого типу цей недолік можна компенсувати мінімальною кількістю балів за кожну правильну відповідь. Проте перевагою стає спрощення процесу підбору змісту запитань, збільшення різноманітності знань, розумінь і навичок, залучених до перевірки. На думку авторів, такі тести доцільно використовувати для перевірки компетентностей репродуктивного рівня. Прикладами таких завдань із дисципліни «Лінійна алгебра» можуть бути такі:

Приклад 3. Дано $W=\langle(1,1,-1,1)\rangle \subset \boldsymbol{R}^{4}$. Чи буде ортогональною проєкиією вектора $(1,0,0,1)$ на підпростір $W$ вектор $(1,1,-1,1)$ ?

Приклад 4. Дано базис $f: e_{1}, e_{1}+e_{2}, e_{1}+e_{2}+e_{3}$. Чи вірно, що вектор $x=e_{1}-2 e_{2}+e_{3}$ в базисі $f$ має координати $(1,-2,1)_{f}$ ?

Безумовно, важливе місце в перевірці знань математичних дисциплін займають тести типу 7, бо математика - це наука про кількісні відношення та просторові форми дійсності, а також вона вирішує потреби людини в обчисленні та кількісному вимірюванні.

Такі тести, як правило, вимірюють лише навички об'єктів навчання репродуктивного рівня. Навіть якщо вони передбачають застосування навичок більш високого рівня, то банальна помилка в обчисленні може привести до невірної відповіді та втрати балів за таке завдання, а допущення окремих суттєвих помилок може не вплинути на числовий результат і дати можливість отримати відповідні бали. Отже, на оцінювання таких завдань також слід виділяти порівняно малу кількість балів. В екзаменаційних білетах завдання такого типу можуть мати такий вигляд:

Приклад 5. Дано $A=\left(\begin{array}{ccc}-1 & -9 & -16 \\ 2 & 8 & 12 \\ -1 & -3 & -4\end{array}\right)$. Знайти характеристичний многочлен А.

Приклад 6. Оператор $A: \boldsymbol{R}^{3} \rightarrow \boldsymbol{R}^{3}$ діє за правилом $A\left(x_{1}, x_{2}, x_{3}\right)=\left(-8 x_{1}+7 x_{2}-16 x_{3},-2 x_{1}+3 x_{2}-4 x_{3}, 4 x_{1}-3 x_{2}+8 x_{3}\right)$. Знайти rang $A$. 
Нарешті, тести відкритого типу (5). Недолік - не перевіряються автоматично. Проте ціла низка переваг:

- можливість перевірити вміння розв'язувати задачі різного рівня складності (і творчого зокрема);

- можливість перевірити й оцінити глибину розуміння матеріалу;

- можливість проявити свою індивідуальність у розв'язанні поставленої задачі.

Такі тести можуть бути вирішальними для з'ясування якості навченості. Наприклад, при 100-бальному оцінюванні всього тесту на всі тести такого типу можна виділити 25 - 30 балів. Прикладами таких завдань можуть бути такі:

Приклад 7. $A, B \in M_{3}(\boldsymbol{R}), A B=|A| \cdot E,\left|(2 A)^{2} \cdot\left(A^{T}\right)^{-1} \cdot B\right|=16$. Знайти $|A|$.

Приклад 8. Дано $U$ та $W$ - лінійні підпростори $\boldsymbol{R}^{4}$, що задовольняють умовам $\operatorname{dim} U>\operatorname{dim} W, U \cap W=\langle(2,3,4,5),(1,1,1,1),(-1,0,1,2)\rangle i(0,0,0,1) \notin U+$ $W$. Знайдіть розмірність $U+W$ та базис $W$.

Приклад 9. Якими можуть бути власні значення лінійного перетворення $\tilde{A}: V \rightarrow V$, що задовольняс умову $\widetilde{A^{2}}-\tilde{A}=6 \tilde{I} ?$

Також важливим етапом у створенні тестів до екзамену є наповнення кожного білету тестовими завданнями. На цьому етапі повинні бути узгоджені загальна (у нашому випадку 100-бальна) система оцінювання та система оцінювання завдань різного типу з урахуванням їхньої кількості; наявність завдань різного рівня складності (репродуктивного, достатнього, високого), причому їхнє співвідношення повинно відповідати співвідношенню показників якості 60:30:10 (задовільно: добре: відмінно). Зміст завдань тесту кожного білету повинен охоплювати весь обсяг навчального матеріалу та не допускати завдань близького змісту. Отже, цей технічний, здавалось би, етап також вимагає методичної обробки.

Насправді цей етап зручно розпочинати до створення змісту завдань, визначивши структуру білета та розподіляючи підготовлені завдання за темами змісту навчального матеріалу.

Висновки. Особливого розвитку в сучасному навчальному процесі набуває такий вид контролю, як тестування. Воно дозволяє отримати об'єктивну, 
Структура та зміст підсумкового контролю в тестовій формі $з$ дисципліни «Лінійна алгебра»

оперативну та достовірну інформацію про знання студентів, отримані під час навчання, та може застосовуватися на різних його етапах.

$\mathrm{У}$ роботі розглянуто можливість та необхідність застосування підсумкового контролю 3 «Лінійної алгебри» у вигляді тесту. Ураховуючи наявний досвід складання тестів, авторами виділено такі перші етапи:

1. Визначення змісту навчального матеріалу.

2. Побудова технологічної матриці.

3. Підбір змісту тестових завдань відповідно до обраних форм тестів.

4. Розподіл тестових завдань між білетами з урахуванням відповідності технологічній матриці та рівносильності за складністю.

Розглянувши різні форми тестів, у роботі виділено ті, які, на думку авторів, найоптимальніше можуть виконати функцію контролю математичних дисциплін. Це тести типу правильно/неправильно, із вибором однієї правильної відповіді, на визначення відповідності, на отримання числової відповіді та відкритого типу. Наведено приклади завдань таких типів.

Дослідження теорії і практики складання тестів на прикладі екзамену 3 лінійної алгебри не можна вважати завершеним. Розроблений екзаменаційний контроль у тестовій формі потребує проведення інших етапів складання тесту: апробація, визначення i розрахунок показників якості тесту, складання остаточного варіанту тесту тощо.

\section{СПИСОК ВИКОРИСТАНИХ ДЖЕРЕЛ}

1. Плащовата, М. С. (2015). Система оцінювання й контролю навчальних досягнень студентів у ВНЗ Німеччини. Теорія та методика навчання та виховання, 37, 95-100.

2. Єремеєвич, М. О., Турка Т. В. (2016). Комп'ютерні системи тестування знань та їх аналіз. Молодий вчений, 5(32), 330-332.

3. Аванесов, В. С. (1994). Методологическое и теоретическое обоснование тестового педагогического контроля. (Дис. д-ра пед. наук). Санкт-Петербург, Российская Федерация: Госуниверситет.

4. Кадневский, В. М., Могиль, О. В., Панфилова, О. Н. (2016). $\quad$ Тесты $\quad$ как социокультурный феномен. Вестник Омского ун-та, 3, 108-110.

5. Кухар, Л. О., Сергієнко, В. П. (2010). Конструювання тестів. Курс лекиій: навч. посіб. Луцьк, Україна.

6. Смолінчук, Л. С. (2010). Тестування як метод оцінювання навчальних досягнень студентів. Вісник національного авіаційного університету. Серія: Педагогіка, Психологія, 03, $74-77$.

7. Фетісов, В. С. (2011). Комп'ютерні технології в тестуванні: навч.-метод. посіб. Ніжин, Україна: Видавець ПП Лисенко М.М.

8. Трегубова, Г. М. (2007). Методологічні основи організації тестового контролю знань студентів. Вісник наиіонального технічного університету України «Київський політехнічний інститут»: Філософія. Психологія. Педагогіка, 4, 139-143. 
Структура та зміст підсумкового контролю в тестовій формі з дисципліни «Лінійна алгебра»

\title{
STRUCTURE AND CONTENT OF THE FINAL CONTROL IN THE TEST FORM WITHIN THE COURSE "LINEAR ALGEBRA"
}

\author{
Zoia Pashchenko \\ Candidate of Physical and Mathematical Sciences \\ Associate Professor of the Department of Teaching Methods \\ of Mathematics and Teaching Methods of Computer Sciences \\ SHEI "Donbas State Pedagogical University" \\ Sloviansk, Ukraine \\ ORCID ID 0000-0003-4544-9242 \\ pashchenko_zd@i.ua \\ Tetiana Turka \\ Candidate of Physical and Mathematical Sciences \\ Associate Professor of the Department of Teaching Methods \\ of Mathematics and Teaching Methods of Computer Sciences \\ SHEI "Donbas State Pedagogical University" \\ Sloviansk, Ukraine \\ ORCID ID 0000-0001-6445-2223 \\ tvturka@gmail.com
}

\begin{abstract}
A quality monitoring and evaluation system is an important mechanism for obtaining high standards of higher education. Monitoring is aimed at determining and evaluating the level of knowledge, skills and competences. One form of automated monitoring is testing. The article justifies the choice of the type of monitoring and evaluation activities in the test form for students of bachelor (the first) educational level, namely, the possibility and necessity of applying the final monitoring in "Linear algebra" in the test form are considered. The first stages of test development are identified; it is the determination of content of educational material, the construction of the technological matrix, the selection of content of test tasks in accordance with the certain test forms, the distribution of test tasks between tickets, taking into account the complexity with the technological matrix and with equivalence.

Having considered various forms of tests, the article highlights those which, according to the authors, can best perform the function of monitoring of mathematical disciplines. These are the correct / incorrect type tests, with the selection of one correct answer, to determine the match, to get the numerical answer, and the open type tests.

The practical task is to create the content of test tasks to check the retained knowledge, taking into account the requirements that exist for this kind of monitoring. Examples of various forms of tests of the final monitoring within the course "Linear Algebra" for students of the faculty of Physics and Mathematics are given.

An important step in developing tests for the exam is filling of each ticket with test tasks. At this stage, a common evaluation system (in our case the 100-point system) and a system for evaluating different types of tasks, should be agreed upon, taking into account their quantity; there should be tasks of different levels of complexity (reproductive, sufficient, high), and their ratio should correspond to the ratio of quality indicators 60:30:10 (satisfactory: good: excellent). The content of the test of each paper covers whole content of the educational material and will not allow similar tasks.

According to the results of the study, a package of papers in the test form of the combined type for the examination within the course "Linear Algebra" for bachelor students of the faculty of
\end{abstract}

Професіоналізм педагога: теоретичні й методичні аспекти. - Вип. 12. - Слов'янськ, 2020. 


\section{3. ПАЩЕНКО, Т. ТУРКА}

Структура та зміст підсумкового контролю в тестовій формі $з$ дисципліни «Лінійна алгебра»

Physics and Mathematics the specialty 014 Secondary Education (Mathematics) of State Higher Education Institution "Donbas State Pedagogical University" has been created. algebra

Key words: knowledge control; testing; test stages; test forms; final certification; linear

\section{REFERENCES}

1. Plashchovata, M. S. The system of assessment and control of students' academic achievements in German universities. Teoriia ta metodyka navchannia ta vykhovannia, 37, 95-100.

2. Yeremeievych, M. O., Turka, T. V. (2016). Kompiuterni systemy testuvannia znan ta ikh analiz. Molodyi vchenyi, 5(32), 330-332.

3. Avanesov, V. S. (1994). Methodological and theoretical substantiation of test pedagogical control. (Doctoral dissertation). St. Petersburg, the Russian Federation: Gosuniversitet.

4. Kadnevskiy, V. M., Mogil, O. V., Panfilova, O. N. (2016). St. Petersburg, Russian Federation. Vestnik Omskogo un-ta, 3, 108-110.

5. Kukhar, L. O. \& Serhiienko, V. P. (2010). Designing tests. Course of lectures: textbook. Lutsk, Ukraine.

6. Smolinchuk, L. S. (2010). Testing as a method of assessing student achievement. Visnik natsionalnoho aviatsiinoho universytetu. Seriia: Pedahohika, Psykholohiia, 3, 74-77.

7. Fetisov, V. S. (2011). Computer technology in testing: teaching method. guide. Nizhyn, Ukraine: Vidavets PP Lysenko M. M.

8. Trehubova, H. M. (2007). Methodological bases of the organization of test control of knowledge of students. Visnyk natsionalnoho tekhnichnoho universytetu Ukrainy "Kyivskyi politekhnichnyi institut": Filosofiia. Psykholohiia. Pedahohika, 4, 139-143.

Матеріали надійшли до редакції 11.03.2020 р. 